\title{
Reproductive biology of the saddle cichlid, Aequidens tetramerus (Heckel, 1840) (Cichliformes: Cichlidae), in small forest streams in the Machado River basin, southwestern Amazonia
}

\author{
Igor David da Costa ${ }^{1 *}$ \\ Missilene Silva de Almeida Fachetti ${ }^{2}$ \\ Natalia Neto dos Santos Nunes ${ }^{3}$ \\ ${ }^{1}$ Instituto do Noroeste Fluminense de Educação Superior, Universidade Federal Fluminense \\ Avenida João Jasbick, s/n, CEP 28.470-000, Santo Antônio de Pádua - RJ, Brasil \\ ${ }^{2}$ Universidade Federal de Rondônia, Departamento de Engenharia de Pesca \\ Rua da Paz, 4.376, CEP 76.916-000, Presidente Médici - RO, Brasil \\ ${ }^{3}$ Universidade Federal de Rondônia, Programa de Pós-Graduação em Ciências Ambientais \\ Avenida Norte Sul, 7.300, CEP 76.940-000, Rolim de Moura - RO, Brasil \\ * Correspondence author \\ igorbiologia@yahoo.com.br
}

Submetido em 29/08/2018

Aceito para publicação em 20/03/2019

\section{Resumo}

Biologia reprodutiva de Aequidens tetramerus (Heckel, 1840) (Cichliformes: Cichlidae) em igarapés na bacia do rio Machado, sudoeste da Amazônia. O objetivo deste estudo foi avaliar a estratégia reprodutiva de Aequidens tetramerus em pequenos riachos na bacia do rio Machado, sudoeste da Amazônia. As amostras foram coletadas em dois igarapés, utilizando rede de cerco e redes de mão ao longo de um trecho de $50 \mathrm{~m}$ do igarapé. Foram coletados 86 indivíduos, sendo 19 machos e 67 fêmeas (proporção-sexual, 3,52 $2_{\text {fêmea }}: 1_{\text {macho }}$ ). O tamanho dos indivíduos variou de 1,5 a $11,5 \mathrm{~cm}$. O tamanho da primeira reprodução para fêmeas foi de $1,8 \mathrm{~cm}$ e dos machos 2,0 cm. A estação reprodutiva da espécie ocorreu no período seco.

Palavras-chave: Amazônia; Desova total; Dinâmica reprodutiva; Fecundidade; Maturação sexual

\section{Abstract}

The aim of this study was to evaluate the reproductive strategy of Aequidens tetramerus in small streams of the Machado river basin, southwestern Amazon. We collected samples in two streams using seine and dip nets along a 50-m stretch of the stream. We collected 86 fishes, 19 males and 67 females (sex-ratio, $3.52_{\text {female }}: 1_{\text {male }}$ ). Their body size varied from 1.5 to $11.5 \mathrm{~cm}$. The size at first reproduction was $1.8 \mathrm{~cm}$ for females and $2.0 \mathrm{~cm}$ for males. The reproductive season of the species occurred in the dry period.

Key words: Amazon; Fecundity; Reproductive dynamics; Sexual maturity; Total spawning 
Knowledge of the reproductive cycle of fishes, including endogenous and exogenous factors that control this activity, are crucial to establishing stock management programs (MIAH, 2015). Recurrent changes in environmental conditions affect fish phenology (CHAPMAN et al., 2005), which is mostly influenced by rainfall and biotic conditions in the tropics (RANGEL-SERPA; TORRES, 2015).

Cichlids show different reproductive strategies, from substrate spawning with low parental care to spawning with vigorous protection (KEENLEYSIDE, 1981; KEENLEYSIDE et al., 1985; BAERENDS, 1993). The cichlid Aequidens tetramerus (Heckel, 1840), is a Neotropical fish species (KULLANDER, 1986; 2003) and presents one of the widest geographic distributions among the neotropical cichlids, being distributed in rivers of the Amazon basin in Bolivia, Brazil, Colombia, Ecuador and Peru, as well as Guyana, French Guiana and
Suriname rivers (QUEIROZ et al., 2013). This species presents ornamental importance (Regulatory Directive 001/2012-MPA/MMA), that consumes mainly food of animal origin, including bryozoans, crustaceans, fish scales, terrestrial insects and detritus (COSTA; SOARES, 2015). Natural reproductive biology of $A$. tetramerus was just investigated in varzea areas of the middle Solimões river (SILVA et al., 2014). Therefore, our objective was to produce information about sexual maturity, oocyte diameter, sex ratio, fecundity and reproductive period of $A$. tetramerus in small streams of the Machado river basin, state of Rondônia, southwestern Amazonia.

Fish sampling took place in the Dom João and Penha streams, located in the Machado river basin in the eastern part of the state of Rondônia (Figure 1). First-order streams have a sandy substratum, pastures covered by non-native grasses such as Urochloa spp.

FIGURE 1: The Machado river basin, showing the study streams sites.

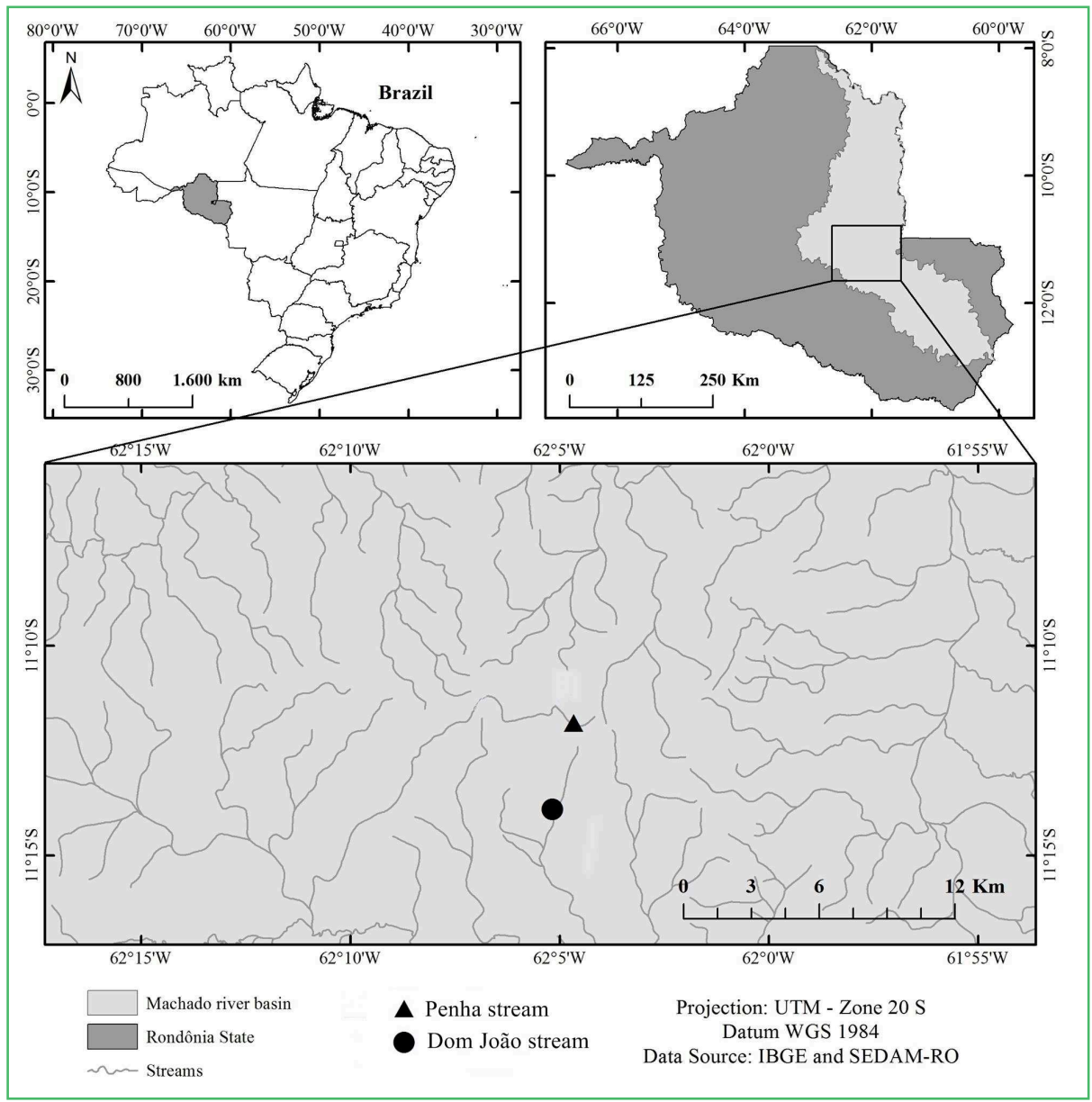


in the adjacent matrix and a small amount of riparian vegetation, such as grass and small aquatic plants. In the dry season, the river measurements were the following: mean depth: $300 \pm 100.0 \mathrm{~cm}$, mean width: $281 \pm 41.1$ $\mathrm{cm}$, mean water speed: $0.4 \pm 0.2 \mathrm{~m} \mathrm{~s}^{-1}$ and mean flow:

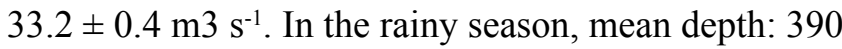
$\pm 130.0 \mathrm{~cm}$, mean width: $316 \pm 47.5 \mathrm{~cm}$, mean water speed: $0.4 \pm 0.0 \mathrm{~m} \mathrm{~s}^{-1}$, and mean flow: $49.2 \pm 0.3 \mathrm{~m} 3 \mathrm{~s}^{-1}$.

Samples were collected every two months from April 2015 to March 2016 along a 50-m stretch of the stream (MENDONÇA et al., 2005). Seine nets (picarés) measuring $2.0 \times 1.20 \mathrm{~m}$, with a $2-\mathrm{mm}$ mesh size and a dip net ( $p u c ̧ a ́)$ with a $0.46 \times 0.33 \mathrm{~m}$ opening and a $2-\mathrm{mm}$ mesh size were used simultaneously along the entire stretch for one hour. The fish were collected under an ICMBio permit (47345-1/2014). Fish were killed with a lethal dose of clove oil, identified following Queiroz et al. (2013) and deposited with voucher number UFROICT 022730.

Standard length $(\mathrm{cm})$ and weight $(\mathrm{g})$ of the specimens were measured. The ovaries and testes were weighed on an analytical scale with a precision of 0.001 g. Different ovarian phases were characterized following Nuñez and Duponchelle (2009). Ovaries from each specimen were selected (ripe stage) and placed in modified Gilson's solution to dissociate oocytes. Oocytes were sorted by size with an oocyte meter, i.e., a device composed of a recipient measuring $15 \mathrm{~cm} \times 12 \mathrm{~cm} \times 30 \mathrm{~cm}$ containing water with nets arranged vertically and mesh sizes ranging from $100 \mu \mathrm{m}$ to $900 \mu \mathrm{m}$ at a decreasing order. Then, the oocytes retained in each mesh were counted under a stereoscope microscope with a 1.2-x magnification. The relative fecundity was determined through the counting of female's vitellogenic oocytes at a ripe stage and shown as number of oocytes per weight unit (VAZZOLER, 1996).

The normality and homoscedasticity tests were used to test the assumptions of the $\mathrm{t}$ test, before testing for differences in length and weight of $A$. tetramerus between sexes. After assessing the normality and homoscedasticity of the data, the differences between males and females were tested by a t-Student test for the length data and a Mann-Whitney (U) test for the weight data. To assess whether the sex ratio was different from expected (1:1) we applied to chi-squared tests $\left(\chi^{2}\right)$ (ZAR, 1999). We used a simple linear regression to test for relationships between oocyte mean diameter and fecundity, fish length and fish weight (ZAR, 1999). The average length at sexual maturity was determined by adjusting a sigmoidal curve to the frequency distribution of sexually mature individuals. The logistical function used was $\mathrm{Y}=1 /(1+\exp (-(\operatorname{tax}) *(\mathrm{x}-(\mathrm{L} 50))))$, where: $\mathrm{y}=$ relative frequency of immature adult males and females in each length class; tax = change rate parameter between non-reproductive and reproductive phases; $\mathrm{x}=$ average value of the standard length class (DUPONCHELLE; PANFILI, 1998). Sexual maturity stages were pooled as immature and mature, following Nuñez and Duponchelle (2009). The reproductive period was defined based on the bi-monthly frequency reproductive females. The analyses were performed in Statistica 7.1 (STATSOFT, 2005). Results were considered significant when $p \leq$ 0.05 .

A total of 86 individual fish were measured. Body size varied from 1.5 to $11.5 \mathrm{~cm}$. The sex ratio was $3.52: 1$ (female: males) $\left(\chi^{2}=23.2 ; \mathrm{df}=1 ; \mathrm{p}<0.05\right)$. The average length $(\mathrm{t}=-0.99 ; \mathrm{df}=62 ; \mathrm{p}=0.32)$ and median weight $(\mathrm{U}=299.0 ; \mathrm{df}=62 ; \mathrm{p}=0.12)$ did not differ between males $(5.4 \pm 2.0 \mathrm{~cm} ; 6.4 \pm 5.2 \mathrm{~g})$ and females $(6.0 \pm$ $1.9 \mathrm{~cm} ; 8.4 \pm 6.0 \mathrm{~g}$ ). There was no significant variation between the oocyte average diameter and fish length $\left(\mathrm{F}=2115.0, \mathrm{R}^{2}=0.04, \mathrm{p}=0.42, \mathrm{n}=16\right)$ and between the individual fish weight $\left(\mathrm{F}=2219.9, \mathrm{R}^{2}=0.03\right.$, $\mathrm{p}=0.47 ; \mathrm{n}=16)$. Fecundity did not show correlation with fish length $\left(\mathrm{F}=-2217.9, \mathrm{R}^{2}=0.09, \mathrm{n}=16\right.$; $\mathrm{p}=0.25)$ (Figure 2$)$ and fish weight $\left(\mathrm{F}=1362.1, \mathrm{R}^{2}=0.09\right.$, $\mathrm{n}=16 ; \mathrm{p}=0.24)$. The average relative fecundity was $3,715 \pm 5,026$ oocytes/g.

The size (standard length) at first reproduction for females was $1.8 \mathrm{~cm}$ (smallest mature female $=1.4 \mathrm{~cm}$ ) (Figure 3). 
FIGURE 2: Relative Fecundity-standard length $(\mathrm{cm})$ of female of Aequidens tetramerus in the Machado river basin, northern Brazil, from April 2015 to March 2016.

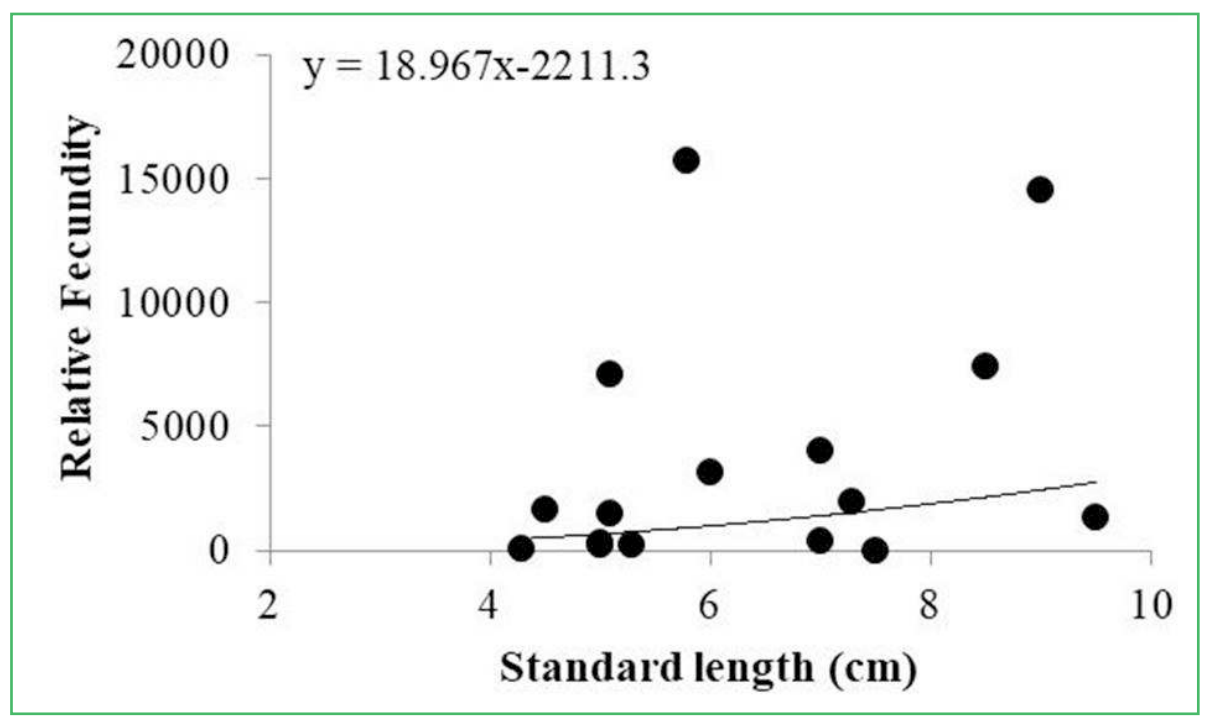

FIGURE 3: Standard length at first reproduction of female of Aequidens tetramerus in the Machado river basin, northern Brazil, from April 2015 to March 2016.

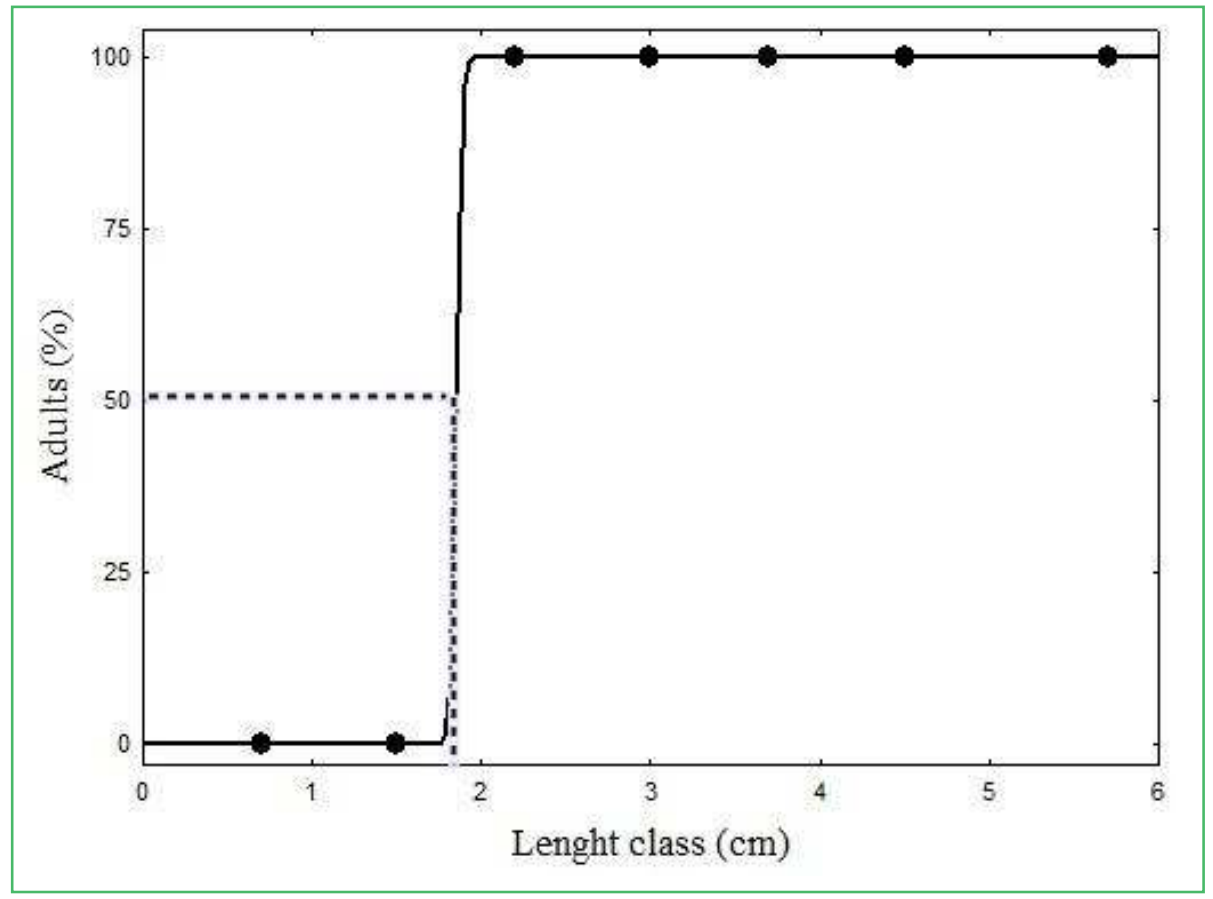

Was no fit of the model to the size at first reproduction for males; the smallest mature male measured $2.0 \mathrm{~cm}$. Although the reproductive season of this species was concentrated in Abril and July, we recorded reproductive individuals throughout the annual cycle (Figure 4).
The classic sex ratio of fish is 1:1 (WOOTTON, 1998) as found for Aequidens tetramerus by Silva et al. (2014) (male-biased sex ratio, 1.2:1), contrasts with our results. Although occasionally recorded in some fish populations, a sexual ratio of 1:1 is rarely expected (VICENTINI; ARAÚJO, 2003) and this 
FIGURE 4: Bimonthly frequency reproductive females of Aequidens tetramerus females in the Machado river basin, northern Brazil, from April 2015 to March 2016.

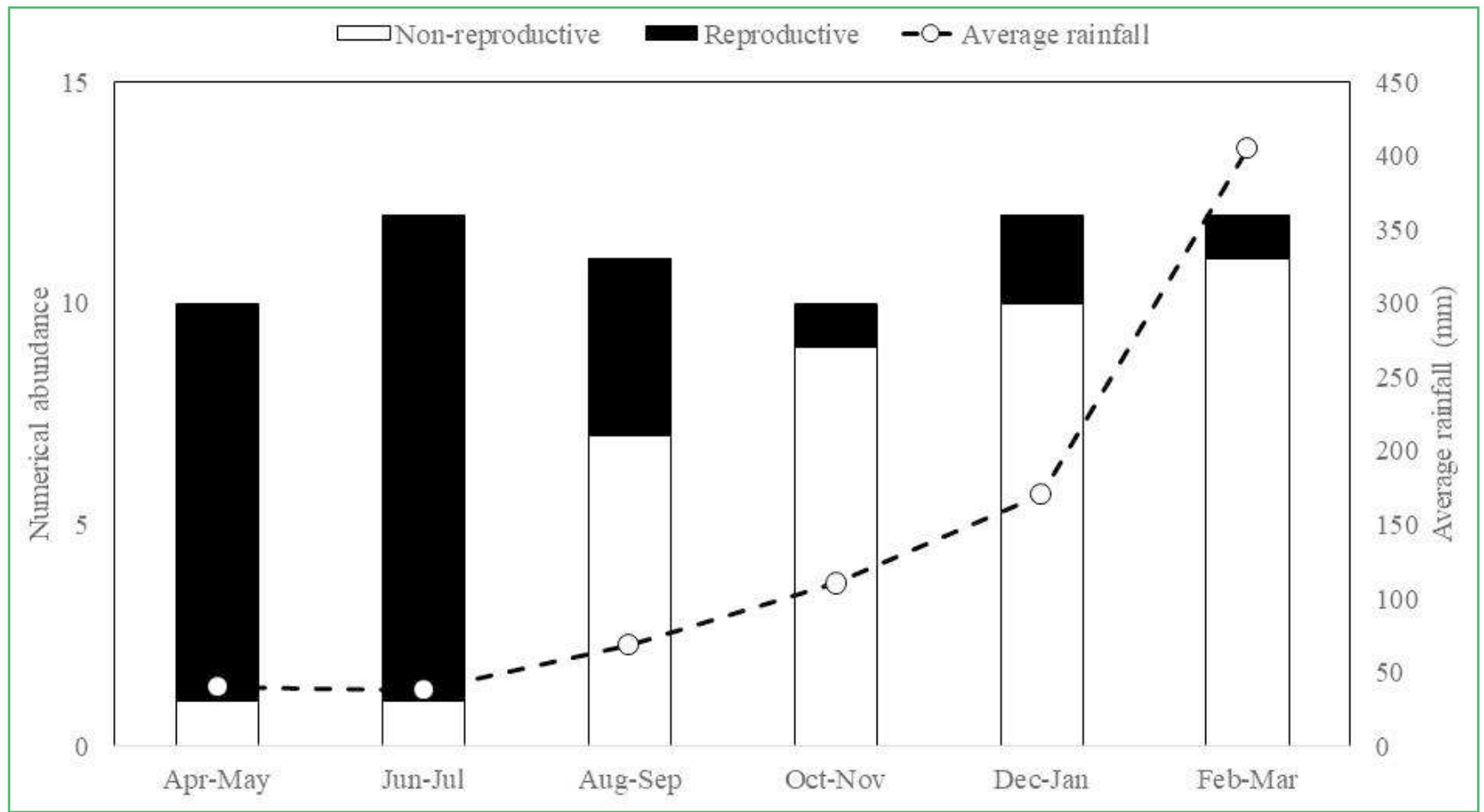

deviation may can be attributed to several causes, such temperature influence in sex determination, mortality as differential predation, sexual behavior growth rate or life expectancy (CONOVER; KYNARD, 1981). The structure of size and sex is specific, and there may be intra and interpopulational variations resulting not only from selectivity, inherent to fishing gear, but also from the conditions environmental factors, mainly food, which interfere with recruitment, growth and mortality (NIKOLSKI, 1969). Another factor that can influence the sexual ratio is the availability of food. Nikolski (1963) reported that where food is plentiful, females predominate and an inverse situation can be observed in where food is limited.

Vazzoler (1996) stated that fecundity and mature oocyte diameter vary according to the size and weight of the female, and increase with growth so that this relationship is more related to the body length than to the age of the animal. However, we did not observe this relationship in A. tetramerus. The absence of a significant relationship between female body size and batch fecundity favors early maturation because the costs of reducing growth rate during earlier life stages are low as the process does not affect future expected fecundity (PIRES et al., 2015). Several factors such as age, nutrition, differences between populations, environmental aspects (CAMPOS-MENDOZA et al., 2004) and the absence or presence of predators (POOTLÓPEZ et al., 2009) interfere with fecundity and oocyte production in a fish species.

Studies showed the genus Aequidens with an average standard length at first sexual maturation of 6.4 $\mathrm{cm}$ for females and $8.3 \mathrm{~cm}$ for males (A. tetramerus; SILVA et al., 2014), and considered it to have precocious gonadal maturation (A. pallidus, WOLF, 2014). It is presumed that a species that reaches sexual maturation prematurely benefits from an efficient mechanism to increase its genetic representation in the next generation as it has a proportionally longer period of reproductive activity throughout its expected lifespan (VAZZOLER, 1996). There are many biotic and abiotic factors that can be involved in the reduction of maturation size, such as an increase in food availability, increase in fishing pressures and predation as mortality agents and 
genetic determination of the species (BARBIERI et al., 2004). Premature sexual maturation could be a strategy developed to reduce the effect of a high predation rate on the population, which can reduce recruitment as the might be removed from the population before having the opportunity to reproduce (QUEIROZ; CRAMPTOM, 1999). Intense and unpredictable environmental fluctuations, such as those that occur in pasture streams, make abiotic conditions of small forest streams favor the species with an opportunistic life strategy, which are characterized by small-sized species, high growth rate, precocious sexual maturation, and long reproductive periods (WINEMILLER; JEPSEN, 1998).

Some studies found another species of the genus, Aequidens pallidus, with reproductive activity in the period of low rainfall (BÜHRNHEIN; COXFERNANDES, 2004; WOLF, 2014). Cichlids in general, show parental care (KEENLEYSIDE et al., 1985; KULLANDER, 1986; 1998; 2003; BAERENDS, 1993), and the rainy season can represent a period in which the reproductive success is low due to the increase in river flow that can force the movement of the offspring and so, increasing predation risk (ESPÍRITO-SANTO et al., 2013). Hence, synchronizing reproduction with the dry season, and higher stability of the small forest streams can result in greater success in reproductive investment.

Most sexual attributes suggest that Aequidens tetramerus has an equilibrium reproductive strategy, in pasture streams (i.e., degraded environments) habitats where our study was conducted already known in varzea lakes of Central Amazonia by Silva et al. (2014). However, it is worth mentioning that the reproductive attributes considered is more typical of fish with an opportunistic strategy: precocious sexual maturity and extended reproductive season. The sum of attributes of different reproductive strategies and life histories can occur to assure the reproductive success in a dynamic, unstable and degraded environment, such as pasture streams.

\section{Acknowledgements}

We are grateful to PIBIC/UNIR for providing an undergraduate research project scholarship for MSAF.
We also thank the anonymous reviewers for their valuable comments.

\section{References}

BAERENDS, G. P. A comparative study of stimulus selection in the filial following response of fry of substrate spawning cichlid fish. Behaviour, Leiden, v. 125, n. 1, p. 79-155, 1993.

BARBIERI, G.; SALLES, F. A.; CESTAROLli, M. A.; TEIXEIRA-FILHO, A. R. Estratégias reprodutivas do dourado, Salminus maxillosus e do curimbatá, Prochilodus lineatus, no Rio Mogi Guaçu, Estado de São Paulo, com ênfase nos parâmetros matemáticos da dinâmica populacional. Acta Scientiarum, Maringá, v. 26, n. 2, p. 169-174, 2004.

BÜHRNHEIM, C. M.; COX-FERNANDES, C. História natural e comportamento reprodutivo de Aequidens pallidus e Crenicichla inpa (Perciformes: Cichlidae). In: CINTRA, R. (Ed.). História natural, ecologia e conservação de algumas espécies de plantas e animais da Amazônia. Manaus: EDUA-INPA-FAPEAM, 2004. p. 157-166.

CAMPOS-MENDOZA, A.; MCANDREW, B. J.; COWARD, K. Reproductive response of Nile tilapia (Oreochromis niloticus) to photoperiodic manipulation; effects on spawning periodicity, fecundity and egg size. Aquaculture, Amsterdam, v. 231, n. 1, p. 299-314, 2004.

CHAPMAN, C. A.; CHAPMAN, L. J.; STRUHSAKER, T. T.; ZANNE, A. E.; CLARK, C. J.; POULSEN, J. R. A longterm evaluation of fruiting phenology: importance of climate change. Journal of Tropical Ecology, Winchelsea, v. 21, n. 1, p. 31-45, 2005.

CONOVER, D. O.; KYNARD, M. H. Environmental sex determination: interaction of temperature and genotype in a fish. Nature, New York, v. 326, n. 1, p. 496-498, 1981.

COSTA, I. D.; SOARES, M. O. The seasonal diet of Aequidens tetramerus (Cichlidae) in a small forest stream in the Machado River basin, Rondônia, Brazil. Acta Amazonica, Manaus, v. 45, n. 4, p. 365-372, 2015.

DUPONCHELLE, F.; PANFILI, J. Variations in age and size at maturity of female Nile tilapia, Oreochromis niloticus, populations from man-made lakes of Côte d'Ivoire. Environmental Biology of Fishes, New York, v. 52, n. 4, p. 453-465, 1998.

ESPÍRITO-SANTO, H. M. V.; RODRÍGUEZ, M. A.; ZUANON, J. Reproductive strategies of Amazonian stream fishes and their fine-scale use of habitat are ordered along a hydrological gradient. Freshwater Biology, London, v. 58, n. 12, p. 2494-2504, 2013.

KEENLEYSIDE, M. H. Parental care patterns of fishes. The American Naturalist, Chicago, v. 117, n. 6, p. 1019-1022, 1981.

KEENLEYSIDE, M. H.; RANGELEY, R. W.; KUPPERS, B. U. Female mate choice and male parental defense behaviour in the cichlid fish Cichlasoma nigrofasciatum. Canadian Journal of Zoology, Ottawa, v. 63, n. 11, p. 2489-2493, 1985.

KULLANDER, S. O. Cichlid fishes of the Amazon River drainage of Peru. Stockholm: Museum of Natural History, 1986. 394 p. 
S. O. A phylogeny and classification of the South American Cichlidae (Teleostei: Perciformes). In: MALABARBA, L. R.; REIS, R. E.; VARI, R. P.; LUCENA, Z. M. S.; LUCENA, C. A. S. (Ed.). Phylogeny and classification of neotropical fishes. Porto Alegre: Edipucrs, 1998. p. 461-498.

KULLANDER, S. O. Family Cichlidae (Cichlids). In: REIS, R. E.; KULLANDER, S. O.; FERRARIS, C. J. JR. (Ed.). Checklist of the freshwater fishes of Central and South America. Porto Alegre: Edipucrs, 2003. p. 605-654.

MENDONÇA, F. P.; MAGNUSSON, W. E.; ZUANON, J. Relationships between habitat characteristics and fish assemblages in small streams of Central Amazonia. Copeia, Lawrence, v. 4, n. 1, p. 751-764, 2005.

MIAH, M. S. Climatic and anthropogenic factors changing spawning pattern and production zone of Hilsa fishery in the Bay of Bengal. Weather and Climate Extremes, Sydney, v.7, n.1, p.109$115,2015$.

NIKOLSKI, G. V. The ecology of fishes. London: Academic Press, $1963.235 \mathrm{p}$

NIKOLSKI, G. V. Theory of fish population dynamics. Edimburg: Oliver \& Boyd, 1969. 138 p.

NUÑEZ, J.; DUPONCHELLE, F. Towards a universal scale to assess sexual maturation and related life history traits in oviparous teleost fishes. Fish Physiology and Biochemistry, Amsterdam, v. 35, n. 1, p. 167-180, 2009.

PIRES, T. H.; CAMPOS, D. F.; RÖPKE, C. P.; SODRÉ, J.; AMADIO, S.; ZUANON, J. Ecology and life-history of Mesonauta festivus: biological traits of a broad ranged and abundant Neotropical cichlid. Environmental Biology of Fishes, New York, v. 98, n. 3, p. 789-799, 2015.

POOT-LÓPEZ, G. R.; ARCE-IBARRA, A. M.; ELÍASGUTIÉRREZ, M.; CERVANTES, A. Differences in reproductive seasonality of the Central American cichlid Cichlasoma urophthalmus from three 'cenotes' (sinkholes). Journal of Applied Ichthyology, Berlin, v. 25, n. 1, p. 85-90, 2009.
QUEIROZ, H. L.; CRAMPTON, W. G. R. Estratégias para manejo de recursos pesqueiros em Mamirauá. Brasilia: $\mathrm{CNPq}$, 1999. $197 \mathrm{p}$.

QUEIROZ, L. J.; TORRENTE-VILARA, G.; OHARA, W. M.; PIRES, T. H. S.; ZUANON, J.; DORIA, C. R. C. Peixes do rio Madeira. São Paulo: Dialeto Latin American Documentary, 2013. $600 \mathrm{p}$.

RANGEL-SERPA, F.; TORRES, M. Reproductive seasonality of Geophagus steindachneri Eigenmann \& Hildebrand, 1922 (Perciformes: Cichlidae) in a tropical mountain river. Neotropical Ichthyology, Maringá, v. 13, n. 2, p. 421-430, 2015.

SILVA, T. C. G.; CAVAlCANTE, D. P.; DE QUEIROZ, H. L. Aspects of the reproductive biology of Aequidens tetramerus (cichlidae) in várzea areas of the middle Solimões river, Brazilian Amazon. UAKARI, Belém, v. 9, n. 2, p. 63-74, 2014.

STATSOFT, INC. Statistica (data analysis software system). 2005. Version 7.1. Disponível em: <http:www.statsoft.com.html $>$.

VAZZOLER, A. E. A. M. Biologia da reprodução de peixes teleósteos: teoria e prática. Maringá: Eduem, 1996. 52 p.

VICENTINI, R. N.; ARAÚJO, F. G. Sex ratio and size structure of Micropogonias furnieri (Desmarest, 1823) (Perciformes, Sciaenidae) in Sepetiba Bay, Rio de Janeiro, Brazil. Brazilian Journal Biology, São Carlos, v. 63, n. 4, p. 559-566, 2003.

WINEMILLER, K. O.; JEPSEN, D. B. Effects of seasonality and fish movement on tropical river food webs. Journal of Fish Biology, Malden, v. 53, n. 1, p. 267-296, 1998.

WOOTTON, R. J. The ecology of teleost fishes. New York: Chapman \& Hall, 1998. 126 p.

WOLF, D. D. D. F. Estrutura populacional, táticas reprodutivas e alocação de energia em peixes de igarapé da Reserva Ducke, Amazônia Central brasileira. 2014. 100 f. Dissertação (Biologia de Água Doce e Pesca Interior) - Instituto Nacional de Pesquisas da Amazônia, Manaus. 2014.

ZAR, J. H. Biostatistical analysis. New Jersey: Prentice Hall City, 1999. $663 \mathrm{p}$. 